\title{
Impact of construction waste minimization at construction site: case study
}

Article

Published Version

Umar, U. A., Shafiq, N., Malakahmad, A., Nuruddin, M. F., Khamidi, M. F. and Salihi, I. U. (2016) Impact of construction waste minimization at construction site: case study. Jurnal Teknologi, 78 (5-3). pp. 33-40. ISSN 2180-3722 doi: https://doi.org/10.11113/jt.v78.8508 Available at https://centaur.reading.ac.uk/66162/

It is advisable to refer to the publisher's version if you intend to cite from the work. See Guidance on citing.

Published version at: http://dx.doi.org/10.11113/jt.v78.8508

Identification Number/DOI: https://doi.org/10.11113/jt.v78.8508

$<$ https://doi.org/10.11113/jt.v78.8508>

Publisher: Penerbit UTM Press

Publisher statement: Copyright of articles that appear in Jurnal Teknologi belongs exclusively to Penerbit Universiti Teknologi Malaysia. This copyright covers the rights to reproduce the article, including reprints, electronic reproductions or any other reproductions of similar nature.

All outputs in CentAUR are protected by Intellectual Property Rights law, including copyright law. Copyright and IPR is retained by the creators or other copyright holders. Terms and conditions for use of this material are defined in the End User Agreement. 


\section{CentAUR}

Central Archive at the University of Reading

Reading's research outputs online 


\section{IMPACT OF CONSTRUCTION WASTE MINIMIZATION AT CONSTRUCTION SITE: CASE STUDY}

Article history

Received

2 June 2014

Received in revised form 5 September 2014

Accepted

25 December 2014

*Corresponding author usmanaumar@yahoo.com

aDepartment of Civil and Environmental Engineering, Universiti Teknologi PETRONAS, 31750 Tronoh, Perak, Malaysia bDepartment of Built Environment, University of Reading, Menara Kotaraya, 80000 Johor Bahru, Malaysia

\section{Graphical abstract}

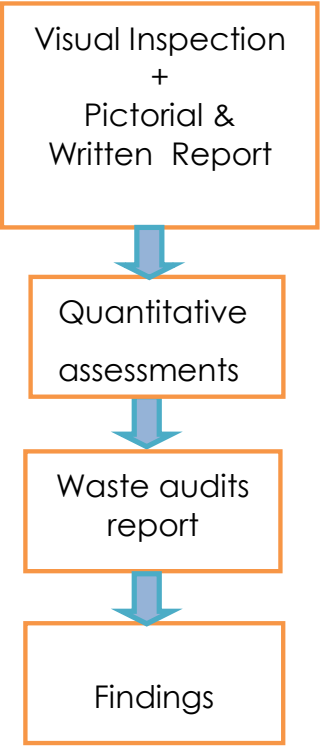

\begin{abstract}
Waste reduction in the construction sector is essential not just from the position of overall performance, but also interests escalated recently about the detrimental impact of the waste of construction materials on the natural surroundings. The reuse and recycling of construction elements used to be substantial due to material scarcity during the war and post-war era, specifically when the price of virgin materials keep inflating. Nevertheless, the motivation to reuse and recycle construction materials has fallen ever since the flow of raw materials has grown more consistent and satisfactorily. This paper involves an ongoing sequence of waste audits at Universiti Teknologi Petronas (UTP) R\&D construction sites. The methodology consists of discussion, observation and quantitative evaluations of the kinds and distribution of wastes. The finding of this study demonstrates that the project aimed at both minimizing the volume of waste generated and diverting as much waste as possible from landfill that contribute to the recycle with over 1200 tonnes of material which constitute about $73 \%$ of recycle and reused rate mainly from timber and metal.
\end{abstract}

Keywords: Waste minimization, construction waste, reuse, recycle

\subsection{INTRODUCTION}

The construction industry is accountable for producing a large multitude of various waste materials, the volume and kind of which relies on conditions like the phase of construction, form of construction work and techniques on-site. Construction and demolition (C\&D) waste is produce during new construction, demolition, and renovation of buildings and structures. C\&D waste consists of, concrete, bricks, soil, rocks, lumber, masonry, soil, glass, plastics, steel, aluminum, drywall, insulation, plumbing fixtures, electrical materials, asphalt roofing materials, corrugated cardboard etc.

Waste material is among the main issue in several developed and developing municipalities around the globe. Waste has long been witnessed as a disaster in these communities since landfill areas are already exhausted at a more speedily pace; whilst planting innovative waste equipment is an extensive 
and meticulous process. The increase of the acquisitiveness and consumptive philosophy has pushed on the creation of waste per capita. With growing understanding for green safety, we have witnessed an increased interest in state-of-art waste management amenities and incorporated answers to the waste challenge. Waste is sometimes considered as a cause of conflict in the politics ground for reasons such as the fixing of waste amenities and the acceptance of various waste management approaches. Continuing growth of the waste sector boasts substantial impacts on the interests of numerous public organizations [1, 2].

Basically, an extremely large amount of waste is believed to occur in buildings. Even though it is hard to methodically evaluate all wastes in construction, many research from different nations around the world have validated that waste presents a comparatively huge proportion of production rates. For instance, the C\&D sector yearly generates three times the volume of waste produced by all United Kingdom homes combined solid waste [3, 4]. Previously, construction waste materials were merely left in wide open places or at the seaside as final process. Many of them used to be utilized in earth filling works yet with little work on wastes separation. Combined construction waste with high-value recyclables were buried simultaneously. Nevertheless, the motivation to reuse and recycle construction materials has decreased from the moment the flow of raw materials has grown more consistent and efficient $[1,5]$. The comparatively affordable cost of virgin materials makes reuse and recycling a much less financially effective alternative [6].

Nowadays, an alternative, incorporated and lifecycle strategy and the waste hierarchy have been employed. Numerous measures aiming the construction technique itself from the planning and designing phase, demolition and construction operation phase and various actions that not particularly focus on the construction method alone were recommended and implemented regularly around the globe to minimize and manage construction waste.

Waste reduction in the construction sector is crucial not just from the perspective of effectiveness, but also interest has been escalating recently concerning the negative effects of the waste of construction materials on the environment. The aim of this paper is to evaluate the impact of construction waste minimization at site by assessing the impact of reused and recycled methods adopted in one of the selected project and highlight the benefit, challenges and future opportunities.

\subsection{LITERATURE REVIEW}

Bossink and Brouwers [7]carried out a study in Holland which focused on the measurement and prevention of construction waste pertaining to achieving sustainability prerequisite mentioned by Dutch environmental guidelines. Waste from seven materials was examined in five dwelling construction tasks. The volume of direct waste by weight varied around 1 and $10 \%$ of the purchased quantity of materials. Also, it was deducted that the average $9 \%$ of the whole purchased construction materials end up as site waste in the Netherlands.

Forsythe [8] outlined the means where construction sector clients are addressing the necessity to enhance environmental efficiency of construction work. They presented a system for examining the effect of waste in the value of a project, such as its removal and disposal. This method applied waste results for six construction materials that varied from 2.5 to $22 \%$ in weight. All these were made due to a scientific research of 15 house-building sites. The research included the quantification of waste in accordance with the level of materials successfully shipped on-site, based on accessible records as well as on interview with officials of various contractors. Jones and Greenwood [3], provided percentage of waste in ten materials as plasterboard $36 \%$, packaging 23\%, cardboard $20 \%$, insulation $10 \%$, timber $4 \%$, chipboard $2 \%$, plastic $1 \%$, electric cable $1 \%$, and rubber $1 \%$. While in another study in Hong Kong, shows that around $5-10 \%$ of building materials turn out to be waste on construction areas [9]. There are numerous contributory elements to this number such as, human, mechanical and so on..

A research in Malaysia indicated, composition and proportion of material debris: Soil $27 \%$, wood $5 \%$, brick and blocks $1.16 \%$, metal product $1 \%$, roofing material $0.20 \%$, plastic and packaging materials $0.05 \%$, concrete and aggregate $65.80 \%$ [10]. Thus, The current methods of managing waste as practiced in Malaysia are highly dependent on landfill due to low operational cost and the absence of alternative treatments [11-13]

\subsection{Reasons for Minimizing Construction Waste Materials}

The construction industry in Malaysia has been long away from environmental concerns like resources effectiveness, waste management, etc. One of the primary influences in Malaysia is the produces waste through their actions. Construction field in Malaysia is among the fastest growing industry, it contributes about 3.8 of the nation Gross domestic product and employs about 800,000 people and produce nearly $32 \%$ of the entire waste generated in the nation. By portion of the waste from this industry goes to landfill sites [14-16].

In addition, the construction sector occupies vast amounts of natural resources and produces a massive volume of construction and demolition (C\&D) waste. This issue is not a remote situation in construction sectors [17], as the modern buildings need to attain certain performance requirements, at least to meet those of building codes, to present a safe, healthy, and comfortable environment [18, 19]. C\&D wastes are huge dimension using up a 
enormous length of area when they are discarded at landfills [11]. Although the amount of C\&D waste received at landfills per capita per day in Malaysia is fairly small in comparison with other places, it is fundamental to minimize the volume of waste materials to be disposed at the landfills. The land supply for landfills and building sites is extremely limited. Minimizing and recycling construction wastes are thus an integral aspect of sustainability in future growth as the construction sector uses a large number of materials. These materials consist of useful natural assets such as wood and steel. Certainly, There is a huge part of the materials being wasted due to negative products handle on construction sites [11].

In cases where the life-cycle of the material, from removal from the nature to their end destiny, is carefully analyzed, a lot of resources could be preserved.

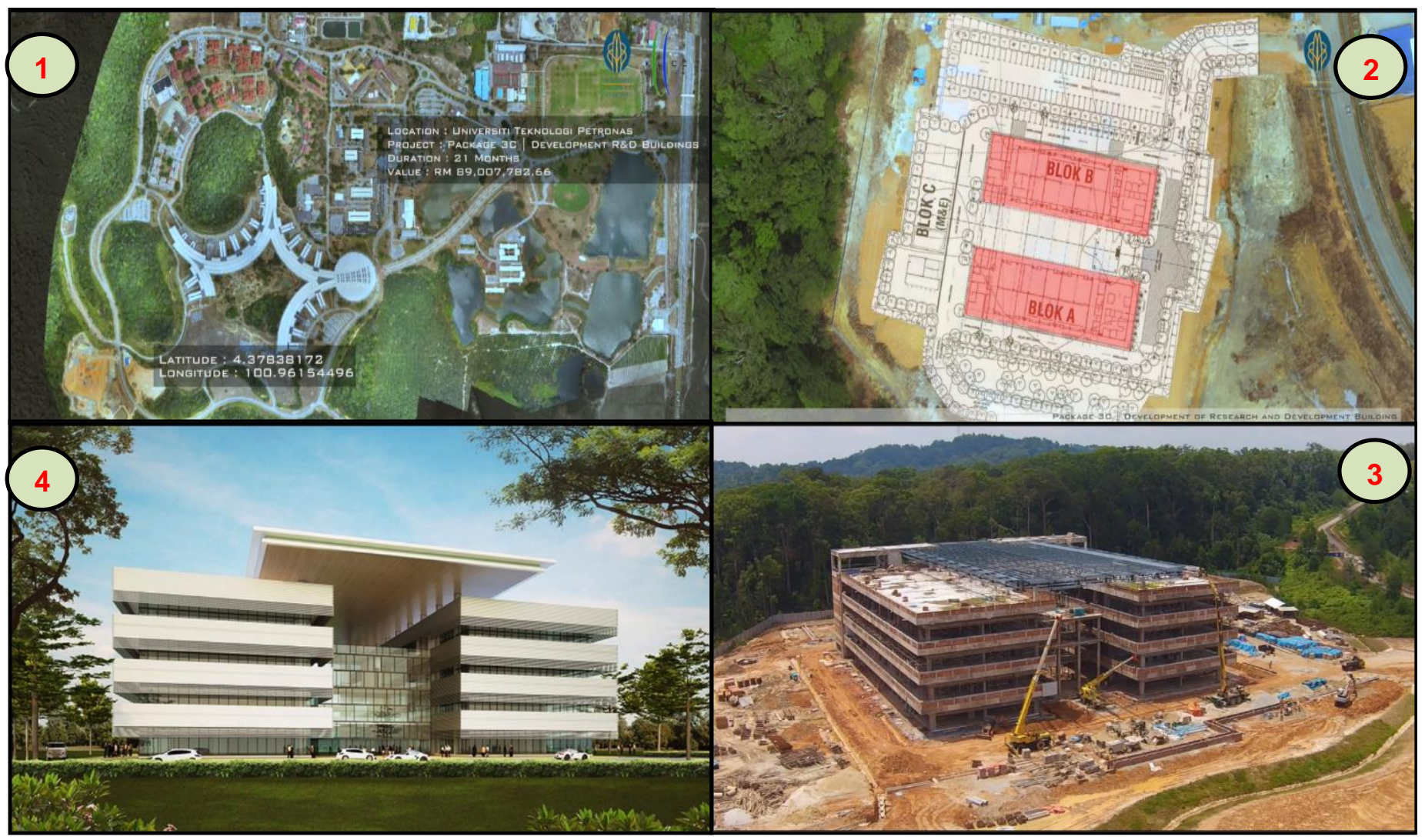

Figure 1 Construction site, UTP R\&D

\subsection{METHODOLOGY}

This paper involves an ongoing number of waste audits at UTP R\&D construction sites. The method consists of discussion, observation and quantitative evaluations of the kinds and delivery of wastes. Mostly, the data is gathered from site audits. Additionally, purchasing stocks were examined against model plans to ascertain materials purchased. The data was then collated at the project site, and past related information were determine for any possible developments in wastes awareness. Ultimately, the data was evaluated on each and every phase of the construction practice, and concerns were brought up about the possibility to minimize waste and the different approaches adopted.

\subsection{RESULTS AND DISCUSSION}

\subsubsection{Case Study Description: UTP R\&D}

An office building was built at UTP by KLCC project and has been designated as a "Green Project" by the company as it includes green approaches and initiative and target towards Green Building Index (GBI) certification. This project was a three-story building (Figure 1), having floor space of 21225 sqm. The company employed numerous approaches for reducing construction waste materials. The concept behind achieving waste minimization had been prescribed to $\mathrm{GBI}$ requirement. Furthermore, cost reduction in waste disposal made this company think about their approaches concerning material procurement and storage. 


\subsubsection{Waste Management Strategies}

The project environmental obligation toward society, other stakeholders, and their prescription to sustainable management efforts position them a step ahead in waste management measures. The company also created a method for sustainability in the project. List of the actions or techniques employed by the company to be able to minimize the operational waste material within this project work were:

- Just in time approach: this way of procuring or ordering the materials required for construction would minimize most of the waste produced during storage and increase managing of the materials on the site.

- Site assessment: assessment and supervising the materials used, the activities being carried out on the site while their storage, managing and real construction work could additional minimize the waste produced throughout these actions.

- Adequate and secured storage of materials: inappropriate material storage on-site would frequently results in a large amount of waste. Therefore, sufficient and secured storage is essential as a way to minimize waste throughout the project activities. Materials such as glass, plasterboards etc. had to be kept appropriately.

\subsubsection{Towards GBI Certification}

According to $\mathrm{GBI}$ certification points throughout construction, it is obligatory to provide dedicated locations and storage space for collecting nonhazardous materials for recycling. This consists of, but is not restricted to wood, concrete, drywall, masonry, roofing materials, structural metal, steel wire, insulation, asphalt, packaging materials associated with $C \& D$ and natural vegetation due to clearing land for development.

The building contractors are to provide a waste management plan showing the selected area of storage and collection of construction waste to be recycled. The project needs to specify the materials to be diverted from discarding and if the materials can be sorted out on-site or commingled. For commingled recycled waste, a summary of diversion rates is needed from the recyclers. The contractor is to recycle and/or salvage at least $50 \%$ by volume of non-hazardous construction waste that is diverted from landfill. Estimated amount of waste to recycle are to be provided in the waste management plan. Names and information of waste management contractor/ salvagers are to be submitted for the Completion \& Verification Assessment (CVA) for evaluation and approval. Details and proof of the amount of materials by measuring the total tonnage of waste of truckloads of waste disposal are to be noted and submitted to the CVA. Table 1 highlights the waste collection summary for the project towards achieving the certification. Furthermore, the contractor is to avoid polluting the surrounding location by means of appropriate disposal of domestic waste produced by on site personnel. Dedicated waste bins should be provided for the storage and disposal.

Table 1 Waste collection summary

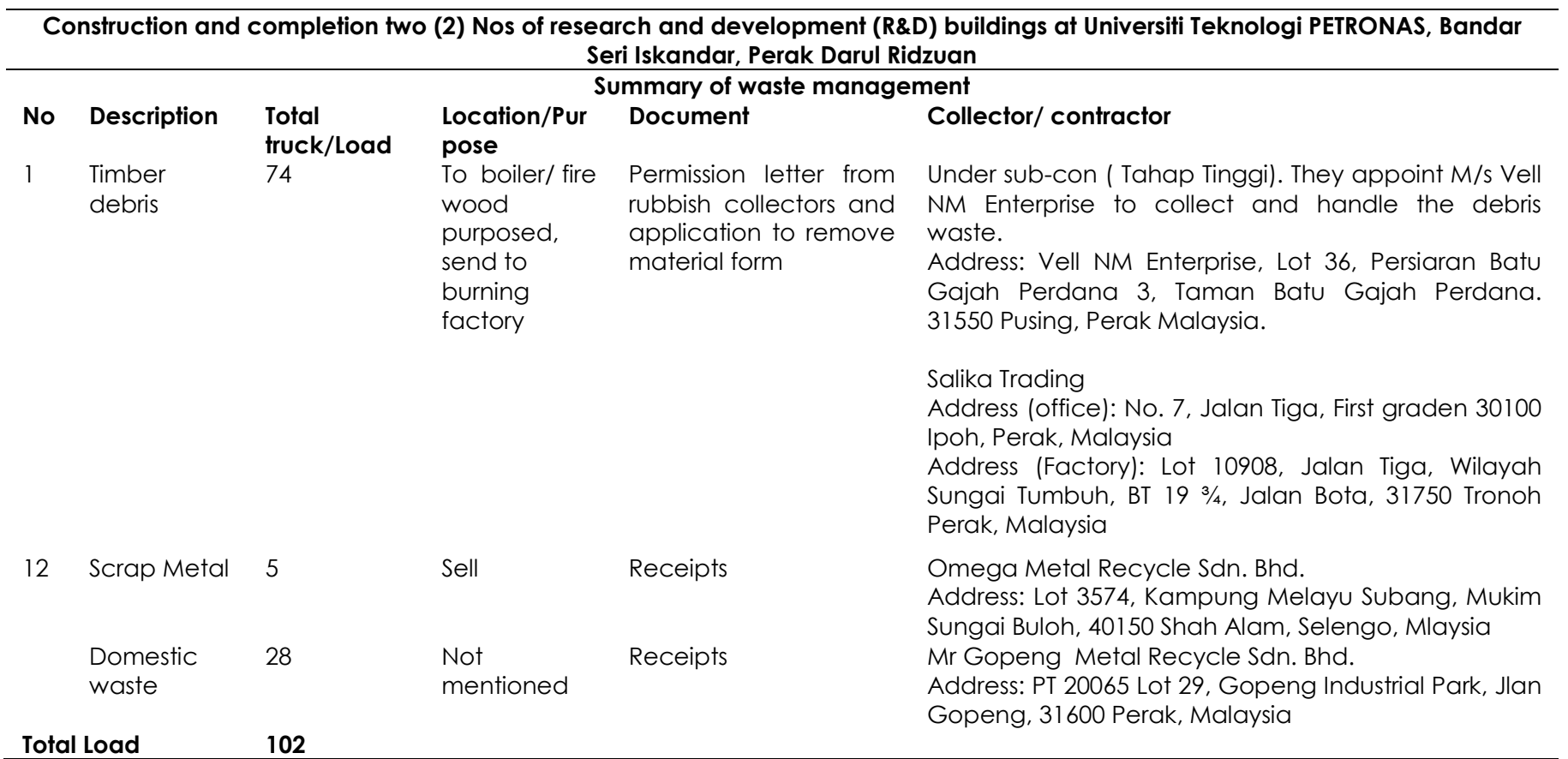




\subsection{Discussion}

\subsubsection{Methods: Project Demonstration}

The UTP R\&D Project focused on both minimizing the amount of waste generated and diverting as much waste as possible from landfill. On-site, the construction manager was designated to be in charge of waste management. In this site the construction manager developed a brief waste minimization plan prior to the project commencement and briefed all sub-contractors on their responsibilities. One point of difference in this study was the absence of a conventional skip. The only bin on-site was for timber as presented in Figure 2. All other waste was collected and dealt with instantly.

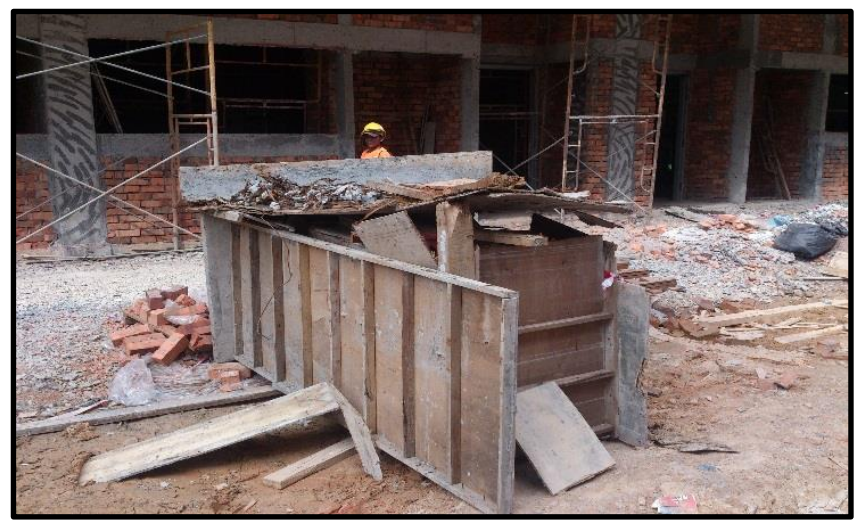

\subsubsection{GBI Point Score}

It is important for the waste management plan (WMP) to commence during the design phase to ensure that waste can be designed out as far as possible. The next phase could be for the design personnel as well as the principal contractor to strategize to reduce the waste material that cannot be designed out. This can be accomplished through packaging minimization, or re-useable packaging options, distribution of adequate area on-site and management, preparation to minimize the possibility of damages to materials, or the off-site prefabrication of elements.

The percentage of full waste that is taken out from site for possibly re-use or reprocessing/recycling is called the 'recycling rate'. An essential variation need to be created between this and the diversion from landfill rate that includes every waste that is generated and is stopped by all means from heading to landfill. Targets for recycling and/or diversion from landfill must be established during the WMP and estimates made concerning waste sources created and how these can be handled. The project score 7 out of the 10 points in material and resources criteria as shown in Table 2 which evidently indicates that material reused and recycled were not satisfactorily at this time, while allocated different collection point for timber and domestic waste as signposted in Figure 3. Furthermore, the WMP was used to document waste removals and be examined at appropriate times by the contractor.

Figure 2 wood waste bin

Table 2 GBI Point Score

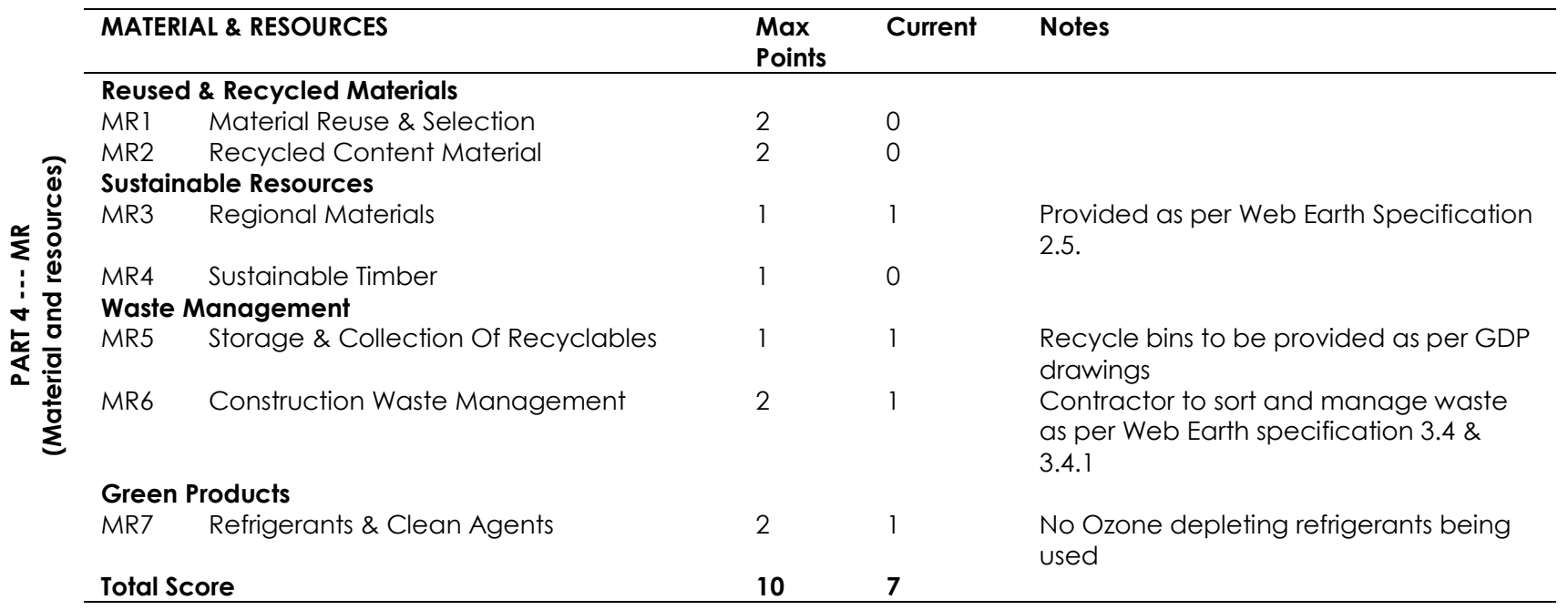




\subsubsection{Material Reused and Recycled}

Reuse and recycling of several materials and resources is developing into industrial standardized process. The UTP R\&D project has recycled over 1200 tonnes of material to constitute about $73 \%$ of recycle and reuse rate mainly from timber and metal while domestic waste were sent to landfill as indicated in Table 3. For instance, antiseptic wood waste is classified and shredded into woodchip. The shredding method eliminates metal particles like bolts, nuts and nails. The reprocessed woodchip is then utilized to be a raw material for identifying end sectors such as particleboard, manufacturing of compost and animal bedding, and as bio filter medium.

Table 3 Recycled construction waste

\begin{tabular}{lll}
\hline Waste Materials & $\begin{array}{l}\text { No of } \\
\text { Truck Load }\end{array}$ & \\
\hline Timber & 74 & Reused \\
Scrap Metal & 5 & Reused \\
Domestic Waste & 28 & Landfill \\
Percentage of truck load reused & $73 \%$ & \\
waste material & & \\
\hline
\end{tabular}

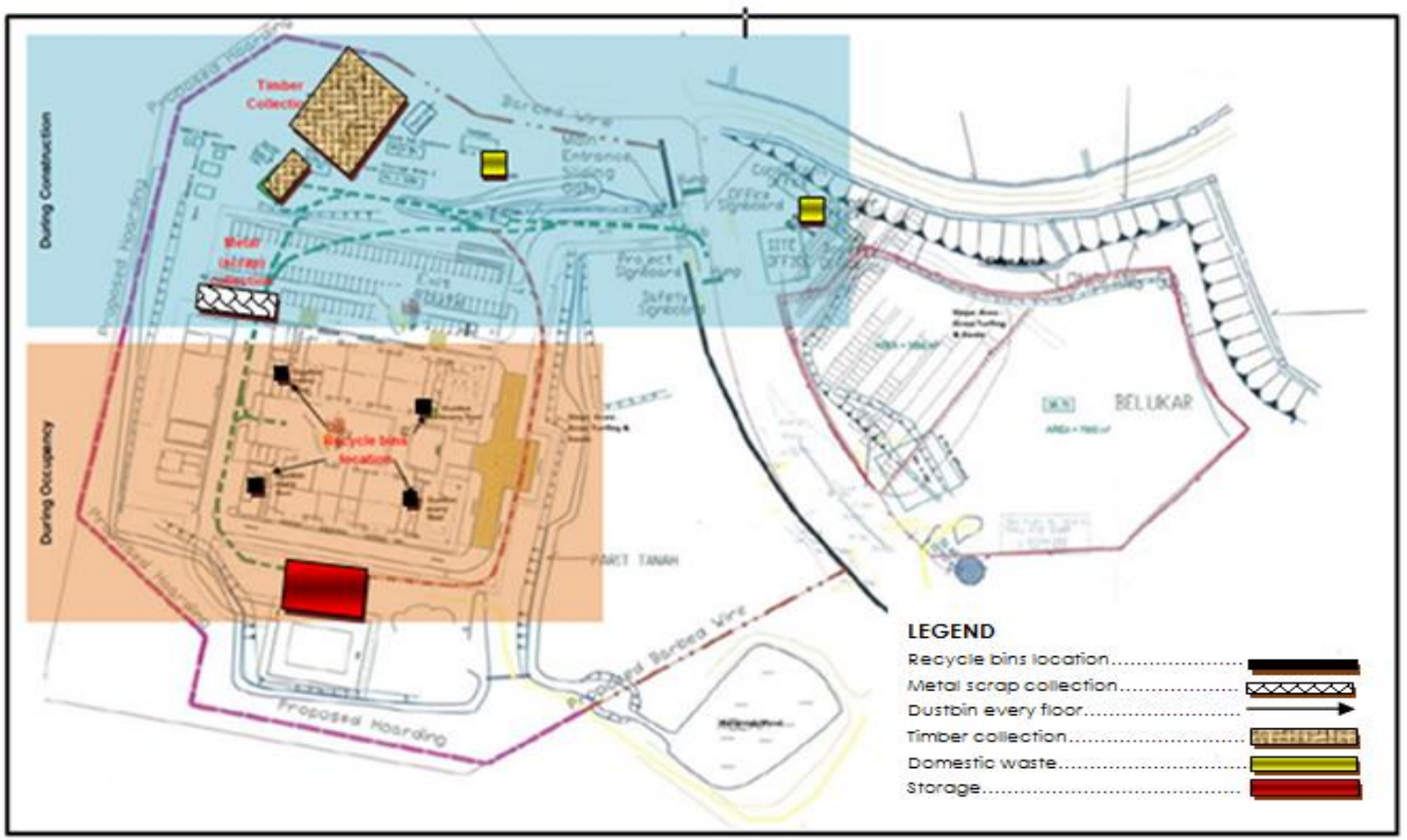

Figure $\mathbf{3}$ Waste collection points

\subsubsection{Benefits and Opportunities}

- The only bin on the site was that of timber and domestic waste any other waste materials were collected and taken off immediately when generated. This site continued to be neat and tidy, and the temptation to keep recyclables in the bin meant for the landfill was eradicated.

- Timber off-cuts were reclaimed by Place Makers, used for noggins, jack studs and blocking.

- Plumbing and drainage off cuts were taken by the supplier.
- Polystyrene off cuts from the cladding were taken back by the supplier who returned them to the maker for recycling.

- Good practice in terms of planning - construction schedule, monitored and updating, ordering materials ahead - meant not doing things in a hurry, but in an organized and coordinated way.

- Regular site reporting - the construction manager Visits the site and keeps records on daily bases (capturing pictures and a few lines of information) thus identified issues/problems as occurred, not afterwards. 


\subsubsection{Drivers for Re-use and Recycling}

The major driver for the sustainability of the construction was the general approach from the clientele, The GBI strategy was applied both as a driver as well as an evaluation of success. Dedication to recycling and re-use throughout the project teams is vital to providing great recycling and re-use rates. Having a knowledgeable and passionate project team that is ready to team up and implement innovative thoughts offers optimum recycling and reuse rates. The team guaranteed that easily obtainable waste materials would be re-used within the fit-out as a substitute for traditional materials. This dedication was considered as a corporate social responsibility and to raise understanding between the workers, foreseeable future project consultancy teams, checking out sub-contractors and overall site guests. The teams followed this idea realizing that maximizing the recycling of excess or discarded materials would guarantee the project ability to minimize landfill and waste generation, preserve natural resources, minimize carbon dioxide, save energy (turning recycled material into new material takes less energy than turning raw material into new material) and make additional job opportunities.

\subsubsection{Challenges}

The client's briefly stated that expenditures have to be well-balanced and that the purchase price should not go beyond that of a traditional fit-out. In this manner the process was to stabilize how long the enhances of recycling and re-use can exist without impacting the finances. From the architect's perspective, indicating recycling of materials can be viewed as a threat because it is difficult to determine the magnitude of recycling that can take place until the project is started. During the project, building contractors involved personnel by carrying information consultations and stakeholder involvement seminars. This allowed them to predict and tackle issues as or perhaps prior to their occurrence. The design teams worked with the construction team to increase possibilities for recycling and re-use rate.

\subsubsection{Specifications and Possibilities for Other Projects}

The lessons learned by the project team accountable for this project will carry forward to future projects and allow the architects and contractors to regularly achieve substantial construction recycling and re-use rates and to minimize costs and time during the design, specification and construction of a building. Carry out a waste management plan for all construction works, regardless of how small. When specifying materials within a new build or refurbishment, the designer has the chance to nominate cladding and materials to be purchased from a reclaimed source within finishes schedule and specification requirements. The head contractor then can present opportunities to the designer and client that could allow materials and products to be reused and diverted from landfill or elimination of the use of virgin materials. All offices need to develop a recycling and waste management plan to motivate enhancements and waste reduction.

\subsection{CONCLUSION.}

The outcomes of this study reveal that waste can be minimized quite successfully if waste minimization is recognized as a section of the contract. On-site segregation of waste and reusing of material was the best widely implemented methods to minimize waste. Furthermore the result shows that, minimizing waste is regarded as an ad hoc activity not an aspect of the central task of the construction. During implementation of the project, it was discovered that employees are not utilized effectively pertaining to minimize waste on site. In essence, the key findings of the study are that construction waste minimization is rewarding for construction companies within the present cost structure for waste disposal in Malaysia. Despite clear economic incentives, waste on many occasions is not really minimized. Lack of minimization is associated with commercial imperative. Local authorities play a vital role in alleviating initial obstacles. Markets are available for a massive amount recoverable; nonetheless they are underutilized. The recycling sector facilities are not well developed or integrated and prospective members have difficulty in getting information and contacting recyclers.

\section{Acknowledgement}

The authors are thankful to Ministry of Education, Malaysia for providing financial support (Grant No. 0153AB-J13) for this research under MyRA grant scheme.

\section{References}

[1] Hostovsky, C. and Maclaren, V. 2005. The Role of Public Consultation in Vietnamese Waste and Other ElAs. First International Conference on Integrated Solid Waste Management in Southeast Asia. 5-6.

[2] Zawawi, E., Yusof, N., Kamaruzzaman, S., and Ismail, Z. 2015. Important Criteria For Managing Disaster Waste In Malaysia. Jurnal Teknologi. 75.

[3] Jones, P. and Greenwood, R., 2003. Construction Waste Minimisation From The UK Housing Sector. Centre for Research on the Built Environment, Welsh School of Architecture. Cardiff University, Cardiff.

[4] Jones, P. and Greenwood, R. 2003. Construction Waste Minimisation in Housing. ed. 
[5] Network, L. R. 2008. History - Waste Management. Available:

http://www.grc.cf.ac.uk/Irn/resources/waste/history.php.

[6] Robinson, G. 2007. Changes In Construction Waste Management. Waste Management World. 3: 43-492.

[7] B. Bossink and H. Brouwers. 1996. Construction Waste: Quantification And Source Evaluation. Journal of Construction Engineering And Management. 122: 55-60.

[8] Forsythe, P. and Marsden, P. 2003. Modelling Construction Waste Performance-An Arising Procurement Issue. Profitable Partnering in Construction Procurement. 427,

[9] Yahya, K. and Halim, Boussabaine A. 2006. Eco-Costing Of Construction Waste. Management of Environmental Quality: An International Journal. 17: 6-19.

[10] Begum, R. A., Siwar, C., Pereira, J. J., and Jaafar, A. H. 2007. Implementation Of Waste Management And Minimisation In The Construction Industry Of Malaysia. Resources. Conservation C.-S.and Recycling. 51: 190-202.

[11] Poon, YU A. T., and Jaillon L., 2004. Reducing Building Waste At Construction Sites In Hong Kong. Construction Management and Economics. 22: 461-470.

[12] Kamyab, H., Lim, J. S., T. Khademi, Hod W. S., Ahmad, R. Hashim, H., et al. 2015. Greenhouse Gas Emission of Organic Waste Composting: A Case Study of Universiti
Teknologi Malaysia Green Campus Flagship Project. Jurnal Teknologi. 74.

[13] Kalanatarifard, A. and Yang, G. S., 2012. Identification of The Municipal Solid Waste Characteristics And Potential Of Plastic Recovery At Bakri Landfill, Muar, Malaysia. Journal of Sustainable Development. 5: 11.

[14] Malaysia, D. 2013. Statistics yearbook Malaysia 2012. Department of Statistics. Malaysia.

[15] D. O. S. Malaysia. Construction. 2013a.

[16] Olanrewaju, A. L. and Abdul-Aziz, A.-R. 2015. An Overview of the Construction Industry. in Building Maintenance Processes and Practices. ed: Springer. 9-32.

[17] Cheung, C., Wong, K., Fan, C., and Poon, C. 1993. Reduction Of Construction Waste: Final Report. The Hong Kong Polytechnic University and Hong Kong Construction Association, Hong Kong.

[18] U. A. Umar, H. Tukur, M. Khamidi, and A. U. Alkali, 2013. Impact of Environmental Assessment of Green Building Materials on Sustainable Rating System. Advanced Materials Research. 398-402.

[19] Umar, U. A., Khamidi, M. F., And Alkali, A. U. 2012. The Repercussions Linked With A Changing Macroclimate For Green Building. In Humanities, Science And Engineering (CHUSER), 2012 IEEE Colloquium on. 392-397. 